\title{
48-Almanca öğretmen adaylarının öğretmenlik mesleğine yönelik tutumları ile meslek alan seçimindeki motivasyonları arasındaki ilişki
}

\section{Şerife ÇELIIKKAYA ${ }^{1}$}

APA: Çelikkaya, Ş. (2022). Almanca öğretmen adaylarının öğretmenlik mesleğine yönelik tutumları ile meslek alan seçimindeki motivasyonları arasındaki ilişki. RumeliDE Dil ve Edebiyat Araştırmaları Dergisi, (26), 795-813. DOI: 10.29000/rumelide.1074082.

\section{$\ddot{O} \mathbf{z}$}

$\mathrm{Bu}$ araştırmada yabancı dil Almanca öğretmen adaylarının "Öğretmenlik Mesleğine Yönelik Tutumları" ile "Meslek Alan Seçimindeki Motivasyonları” arasındaki ilişkinin araştırılması hedeflenmiştir. Araştırma ilişkisel tarama modelinde tasarlanmıştır. Araştırmanın örneklemi Anadolu Üniversitesi Eğitim Fakültesi Yabancı Diller Eğitimi Bölümü Almanca Öğretmenliği Programında çalışmaya gönüllü olarak katılan toplam 113 birinci, ikinci, üçüncü ve dördüncü sınıf öğretmen adayıdır. Araştırmanın verileri; Üstüner (2006) tarafından geliştirilen “Öğretmenlik Mesleğine Yönelik Tutum Ölçeği” ve Mayr (1998) tarafindan geliştirilen Türkçeye Atav ve Altunoğlu (2013) tarafından uyarlanan "Meslek ve Alan Seçiminde Motivasyon Ölçeği” aracılığıyla toplanmıştır. Araştırmanın bağımlı değişkenleri, meslek alan seçme motivasyon ölçeğinin iki alt boyutu (içsel ve dışsal), bağımsız değişkeni de öğretmenlik mesleğine yönelik tutumlarıdır. Veriler SPSS (Statistical Package for the Social Sciences) programı ile çözümlenmiş ve verilerin analizinde betimsel istatistik yöntemlerinden aritmetik ortalama, standart sapma, Pearson korelasyon katsayısı kullanılarak iki yönlü varyans analizi (ANOVA) yapılmıştır. Araştırmadan elde edilen sonuçlar incelendiğinde araştırmaya katılan öğretmen adaylarının öğretmenlik mesleğine yönelik tutumları ile meslek ve alan seçimi motivasyonları arasında pozitif yönlü ilişki sonucuna ulaşılmıştır. Araştırmadan elde edilen bir diğer sonuç ise öğretmen adaylarının içsel ve dışsal meslek alan seçimleri arasında cinsiyete ve sınıf düzeyinde anlamlı bir farklılığın olmamasıdır. Öğretmen adaylarının daha başarılı bir meslek yaşamı için mesleğe yönelik olumlu tutum sergilemeleri sağlanmalıdır.

Anahtar kelimeler: Öğretmen Adayı, tutum, meslek ve Alan seçim motivasyonu

\section{The relationship between German pre-service teachers' attitudes towards teaching profession and their motivation on profession choice}

\begin{abstract}
In this study, it was aimed to examine the relationship between German language pre-service teachers' "Attitudes towards Teaching Profession" and "Motivation on Teaching Profession Choice". The research was designed in correlational survey model. The sample of the study consisted of totally 113 first, second, third grade and senior pre-service teachers who voluntarily participated in the study and who studied at Anadolu University Faculty of Education, Department of Foreign Language Education, German Language Teaching Program. The research data were collected through the "Attitudes towards Teaching Profession Scale" developed by Üstüner (2006) and the "Motivation on Profession and Field Choice Scale" developed by Mayr (1998) and adapted into Turkish by Atav and Altunoğlu (2013). The dependent variables of the study are two sub-dimensions (internal and
\end{abstract}

Dr. Öğr. Üyesi, Anadolu Üniversitesi, Eğitim Fakültesi, Yabancı Diller Eğitimi Bölümü, Alman Dili Eğitimi ABD (Eskişehir, Türkiye), scelikka@anadolu.edu.tr, ORCID ID: 00oo-0002-3346-4050 [Araştırma makalesi, Makale kayıt tarihi: 28.10.2021-kabul tarihi: 20.02.2022; DOI: 10.29000/rumelide.1074082]

Adres $\mid$ Address

RumeliDE Dil ve Edebiyat Araşttrmaları Dergisi Osmanağa Mahallesi, Mürver Çiçeği Sokak, No:14/8 Kadıköy - İSTANBUL / TÜRKIYE 34714 e-posta: editor@rumelide.com

RumeliDE Journal of Language and Literature Studies Osmanağa Mahallesi, Mürver Çiçeği Sokak, No:14/8 Kadıköy - ISTANBUL / TURKEY 34714

phone: +90 $5057958124,+902167730616$ 
796 / RumeliDE Journal of Language and Literature Studies 2022.26 (February)

The relationship between German pre-service teachers' attitudes towards teaching profession and their motivation on profession choice / Ş. Çelikkaya (pp. 795-813)

external) of the motivation for choosing a profession scale, and the independent variable is attitudes towards the teaching professionThe data were analyzed with the SPSS (Statistical Package for the Social Sciences) program, and two-way analysis of variance (ANOVA) was performed using descriptive statistical methods such as arithmetic mean, standard deviation, and Pearson correlation coefficient. When the results obtained from the study were investigated, it was concluded that there was a positive relationship between pre-service teachers' attitudes towards teaching profession and their motivation on teaching profession and field choice. Another result obtained from the study was that no significant difference was found in pre-service teachers' internal and external professional field choices in terms of their gender and grades. For a more successful professional life it should be ensured that teacher candidates have a positive attitude towards the profession.

Keywords: Pre-service teacher attitude, professional and field choice motivation

\section{Giriş}

Sürekli gelişen ve değişen dünyada tüm devletlerin en önemli çabası, değişim ve gelişmelere ayak uydurmak için gerekli olan yeterliliklere sahip nitelikli ve üretken bireyler yetiştirmektir. Eğitimin bu amaca ulaşabilmede en etkili aracın olduğunu, bu aracın en önemli unsurunun da öğretmen olduğu bilinmektedir çünkü öğretmenin eğitimin diğer unsurlarını etkileme ve şekillendirme gücünün çok fazla olduğu bilinen bir gerçektir. Öğretmen, örgün eğitim kurumları olarak adlandırdı̆̆ımız okullarda öğretimi sağlayan ve belirlenen program dâhilinde yapılması gereken eğitim etkinliklerini düzenleyen ve öğrencilerin davranışlarında istendik ve kalıcı değişiklikler saylayan eğitimcidir (Erden, 1998: 38). Ayrıca öğretmen geçmişte olduğu gibi günümüzde de temel becerilerin kazandırılmasında eğitim sistemi için en vazgeçilmez öğelerdendir çünkü öğretmen bireylerin sosyal yaşantılarını şekillendiren onları toplumsal hayata hazırlayan, kültür ve değerlerini tanımalarına olanak sağlayan en önemli kişidir (Kaya, 2001: 9). Bu nedenle de bireylerin karşılaştı̆̆ı sorunları kolayca çözebilmeleri ve toplumsal norm ve değerlere uyum sağlayabilmeleri, gerekli yetkinlik ve yeterlilikleri kazanabilmeleri; vatana ve millete yararl, bilimsel, çalışkan ve üretken bireylerin yetiştirilme sürecinde en önemli görev ve sorumluluk öğretmenlerindir (MEB 2017). Kısacası öğretmeni bireylerin davranışlarının şekillenmesine etki eden bir mimar, bireyin kişiliğini biçimlendiren bir sanatkâr olarak görmek mümkündür (Şişman, 200o). Bu nedenle eğitim sisteminde öğretmen adaylarının iyi yetiştirilmesi, oldukça önemli bir yere sahiptir (Yeşil ve Çalışkan, 2006: 56). Öğretmenlerin hem nitelikli hem de çağın gerektirdiği tüm becerilerle donatılmış olması yalnızca iyi bir öğretmen yetiştirme programı ile mümkündür. Ancak bu programı alacak olan öğretmen adaylarının da öncelikle bu mesleğin kendilerine uygunluğunu, bu mesleğe yönelik eğitim almaya ne derece gönüllü, istekli ve olumlu tutum içinde olduklarını bilmeleri de büyük derecede önem arz etmektedir. Olumlu tutum içinde olan adayların bu mesleği seçmeleri nitelikli öğretmen yetiştirmek için gerekli olan ilk adım olarak nitelendirilebilir. Çünkü hangi mesleği yapmak istediğini bilen ve bu meslekte de en iyisi olabilmek için yeterliklerini geliştirmeye, eksiklerini gidermeye çaba gösteren adayların bu doğrultuda daha çok çalışma arzusu içinde olacakları düşünülmektedir (Demirtaş, Cömert ve Özer, 2011). Bu nedenle de Eğitim Fakültelerini öğretmen olmaya istekli adayların tercih etmesi son derece önemlidir. Ayrıca adaylara özellikle eğitimlerinin ilk yıllarında öğretmenliğin bir uzmanlık gerektiren bir meslek olduğu bilinci kazandırılmalıdır (Şimşek, 2005).

Öğretmenlik mesleğinin üç temel boyutunu genel kültür, meslek ve alan bilgisi oluşturur (Demirel, 1999). Yürürlüğe 1973 yılında girmiş olan Milli Eğitim Temel Kanunu'nda (Sayı 1739 Madde 43) öğretmenlik, özel bir meslek olarak tasvir edilmiş ve eğitim, öğretim ve bunlarla ilişkili olan yönetim görevlerine dikkat çekilmiştir (Özdemir ve Yalın, 2000). Bir kişinin öğretmen olabilmesi için öğretim

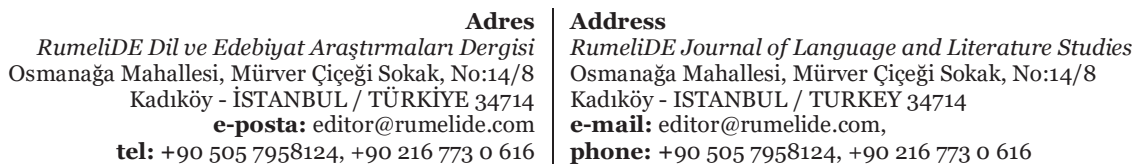

RumeliDE Journal of Language and Literature Studies

Osmanağa Mahallesi, Mürver Çiçeği Sokak, No:14/8

Kadıköy - ISTANBUL / TURKEY 34714

e-mail: editor@rumelide.com

phone: +90 $5057958124,+902167730616$ 
kademesine bakılmaksızın, yükseköğrenim görmesi temel alınmış ve hangi bölümden mezun olursa olsun bireylerin; mesleki alan bilgisine, mesleğin gerektirdiği beceriler ile tutum ve değerler açısından gerekli yeterliliklerle donatılması gerektiği belirtilmiştir (MEB 2017). Görüldüğü gibi öğretmen adaylarının aldıkları eğitimi başarılı bir şekilde uygulayabilmeleri ve belirtilen özelliklere sahip, donanımlı bir öğretici olabilmeleri için eğitim sürecinde edindikleri bilgileri kendi özellikleri ile bir araya getirerek kullanmaları gereklidir. Aynı zamanda öğretmenlik mesleği, çă̆ın getirdiği gelişmeleri ve değişimleri takip etmeyi, kişinin kendisini sürekli geliştirmesini, sabretmeyi bilen ve fedakârca çalışmayı gerekli kılan bir meslektir. Bu nedenle de öğretmen adaylarının mesleklerine karşı olumlu tutum içinde olmaları beklenmektedir. Çünkü tutum "davranışları belirleyen etmenlerden birisidir ve kişilerin meslekleri için gereken davranışları geliştirebilmelerini sağlamaktadır (Çağlar, 2013)”.

Tutuma yönelik alanyazında farklı tanımlar yer almasına rağmen, kuramcıların çoğunluğu, tutum için obje ya da objeler gruplarına gösterilen tepki (Lett, 1977: 269) ifadesinde ortak fikirde birleşmektedirler. Tutumu kısaca herhangi bir obje, kavram olay ya da herhangi bir bireye karşı gösterilen tepki olarak tanımlamak mümkündür (Tezbaşaran, 1997; Demirel, 2003; İnceoğlu, 2004).

Öğretmen adaylarının da kendilerine meslek olarak seçtikleri öğretmenlik mesleğine karşı olumlu tutum içinde olmaları edindikleri beceri ve bilgiler kadar gereklidir (Özkan, 2012). Mesleğe yönelik tutum aslında kişinin o mesleği nasıl yapacağına dair bir göstergedir. Mesleğine yönelik olumlu tutum içindeki birey mesleğini isteyerek ve severek yaparken, olumsuz tutum içindeki birey de mesleğini isteksiz ve gönülsüz yapacaktır. Bu nedenle de olumlu tutum içinde olup mesleğini severek yapan bir öğretmenin başarılı olma olasılığı sevmeyene göre daha yüksek olacaktır (Çiçek-Sağlam, 2008) çünkü herhangi bir meslek ya da işe karşı gösterilen tutum ve algılar, mesleki başarı ve yeterlilikleri etkilemektedir (Terzi ve Tezci, 2007). Öğretmenlerin mesleklerine karşı geliştirecekleri olumlu tutum sayesinde görevlerini eksiksiz yerine getirebilecekleri bilinmektedir. Böylelikle öğretmenlerin araştırmacı bakış açısıyla yaratıcı düşünmelerini geliştirebilecekleri, öğrencileri kolaylıkla motive edebilecekleri, öğrencilere yönelik sözel ya da sözel olmayan mesajları uyumlu bir biçimde aktarabilecekleri, vakti verimli kullanabilecekleri ve farklılıklara açık olabilecekleri belirtilmektedir (Çeliköz ve Çetin, 2004). Unutulmamalıdır ki tutum bu alanda gerekli olan her şeye (öğrenciye, öğrenmeye v.b) büyük oranda etki etmektedir.

Alan yazın incelendiğinde öğretmen yetiştirme programlarının çeşitli bölümlerindeki öğretmen adaylarının öğretmenlik mesleğine yönelik tutumlarının incelendiği farklı araştırmaların yapıldığı görülmektedir (Üstün, Erkan ve Akman, 2004; Çeliköz ve Çetin, 2004; Işık, Yaman ve Soran, 2005; Kaya ve Büyükkasap, 2005; Güdek, 2007; Bedel, 2008; Pehlivan, 2008; Bulut, 2011; Aydın ve Sağlam 2012; Uyanık 2017; Kayhan, Baysan ve Alcı 2018). Bu çalışmalara karşın Yabancı Diller Eğitimi Bölümü Almanca Öğretmenliği programında öğrenim gören geleceğin meslek sahiplerinin tutumlarını inceleyen daha az sayıda araştırmanın bulunduğu görülmektedir (Köydemir, 2004; Uslu, 2004; Alyaz, 2011; Atmaca, 2015). Yapılan araştırmaların bazılarında öğretmenlik mesleğine yönelik tutumların öğretmen adaylarının öğrenim gördükleri lisans programına göre değişmediği ifade edilirken (Bozdoğan, Aydın ve Yıldırım, 2007; Çetinkaya, 2009, İlter ve Köksalan, 2011; Aydın ve Sağlam, 2012); bazılarında ise öğretmenlik mesleğine yönelik tutumların öğretmen adaylarının öğrenim gördükleri lisans programına göre farklılık gösterdiği sonucuna ulaşılmıştır (Aksoy, 2010; Demircioğlu ve Özdemir, 2014; Kayhan, Baysan, ve Alcı, 2018).

Bu farklılıkların oluşmasına lisans programından mezun olunan alana yönelik atanma kolaylığının olup olmaması, öğretmen atamalarında kontenjanların yetersiz olması, MEB'e bağlı okullarda mezun olunan

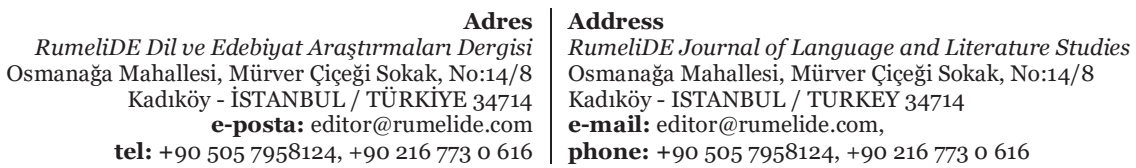


The relationship between German pre-service teachers' attitudes towards teaching profession and their motivation on profession choice / Ş. Çelikkaya (pp. 795-813)

lisans programın ders saatinin az ya da çok olması, KPSS sınavından atanma için gerekli puanın alınıp alınmayacağı gibi etkenleri saymak mümkündür (MEB 2017). Tüm sayllan bu etkenler öğretmen adaylarının öğretmenlik mesleğine yönelik olan tutum ve motivasyonlarını etkilemektedir. Mesleğinde başarılı olmak isteyen birey alanı ile ilgili öğrenmelere de açlk olacak ve mesleğinde başarııı yakalayabilmek için olumlu tutum ve motivasyon içinde kendini geliştirmeye çalışacaktır. Çünkü motivasyon "bireyin öğrenmesin etkileyen önemli bir faktördür (Chen, 2001)" ve olumlu olduğunda da başarıyı getirdiği bilinmektedir (List, 2002; Wicke, 2004; İşigüzel, 2012; Sarıer, 2016).

Motivasyonun bir insanı amacına ulaşması için harekete geçiren bir iç durum (Eren, 2012: 498) olduğu belirtilirken, başka bir ifade de motivasyonun bireyin davranışa geçmesine neden olan, bu davranışlara düzenlilik ve süreklilik veren, yönünü ve amacını belirleyen, çeşitli içsel ve dışsal etkenler ile bunların işleyişini sağlayan mekanizmalar olduğu belirtilmektedir (Aydın, 2010). Kısacası motivasyonu, toplumların istendik şekilde davranış ve eğilim göstermelerini sağlayan çevre ya da bireyden kaynaklı dürtü ve güdüler olarak tanımlamak mümkündür (Ercan, 2000).

Öğrenme ve öğretme süreçlerinde motivasyonun önemli kavramlar arasında yer alması sebebiyle, motivasyonu içsel ve dışsal motivasyon olarak iki türe ayırmak mümkündür (Woolfolk,1999; 157-167; Ryan ve Deci, 2000; Martin ve Steffgen 2002; Edelmann, 2003). Dışsal motivasyonda bireyin dışsal faktörlerden etkilendiği ve olumlu davranışa yöneldiği, içsel motivasyonda ise bireyin itici bir nedene ihtiyaç duymaksızın bir davranışı yapmak istediği belirtilmektedir (Sağlam, 2007). İçsel nedenleri: eğitim yönünden çocuklarla ilgilenme, bilgiyi aktarma, toplumsal açıdan önemli bir görevi yapma, öğretmenlik mesleğinin çok yönlülügü; dişsal nedenleri: çalışma saatlerinin uygunluğu, iş garantisi, iş ve aile hayatının birlikte kolay bir biçimde yürütülebilmesi şeklinde sıralamak mümkündür (Young 1995; Urhahne 2006). Özellikle de kişileri başarılı olmaya yönlendiren içsel süreç farklı istek ve gereksinimlerden etkilendiği gibi bireyler arasında da farklılık gösterebilmektedir. Bu da kişilerin meslekleriyle ilgili farklı davranış ve performans göstermelerine neden olabilmektedir.

Meslek edinme amacıyla Eğitim Fakültelerinin çeşitli anabilim dallarının öğretmen yetiştirme programlarında öğrenim gören öğretmen adaylarının yüksek motivasyonla öğrenimlerini tamamlamaları ve olumlu motivasyonlarını meslek olarak seçtikleri öğretmenliğe yansıtmaları oldukça önemlidir. Alanyazın incelendiğinde öğretmenlik mesleğinin farklı alanlarında öğrenim gören öğretmen adaylarının motivasyon seviyelerini ve bunları etkileyen değişkenlerin birçok araştırmanın konusu olduğu görülmüştür (Acat ve Yenilmez, 2004; Gençay ve Gençay, 2007; Özgüngör ve Kapıkıran, 2008; Saracaloğlu ve Dinçer, 2009; Dereli ve Acat, 2010; Şahin ve Çakar, 2011; Öztürk Akar, 2012; Ünal ve Bursalı, 2013; Uyulgan ve Akkuzu, 2014; Küçükosmanoğlu, 2015; Ulutaş, 2016). Ancak yabancı dil alanında öğrenim gören öğretmen adaylarının motivasyon düzeylerini konu alan çalışmalar ise oldukça sınırlı sayıdadır (Gardner ve Lambert, 1972; Kızltepe, 1999; List, 2002; Dellal ve Günak, 2009; İşigüzel, 2012).

Geleceğin öğretmenleri olacak olan öğretmen adaylarının yüksek motivasyona sahip olmaları, mesleklerinin gerekleri için ne kadar motive olduklarının bir göstergesi olarak düşünülebilir. Mesleğin gerekleri için motivasyonu yüksek olan kişilerin etkili bir öğretim yapacakları da bilinmektedir. Özellikle de öğretmen adayı istediği, sevdiği ve geçerli bir alanla ilgili öğretmenlik eğitimi alıyorsa bu onun motivasyonunu daha da yükseltecektir (Dann ve Lechner 2001; Ulich 2004). Ancak aday istemediği, benimsemediği hatta hiç uyuşmadığı bir alan ile ilgili eğitim alıyorsa bu onun mesleki motivasyon düzeyini olumsuz yönde etkileyeceği gibi görev yapacağı kurumu, sınıfı, öğrenciyi ve meslektaşlarını da belli ölçüde etkileyeceği muhakkaktır.

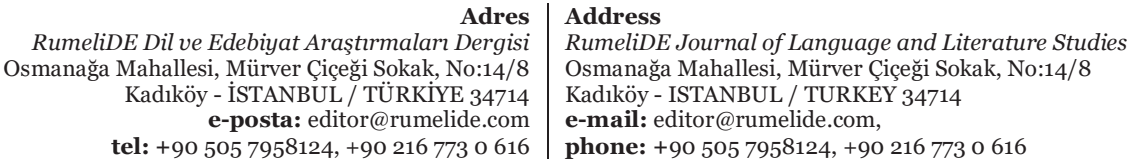


Tüm alanlarda adayların öğretmenlik mesleğine yönelik tutumları ve bu alanları seçmedeki motivasyonları ve düzeyi oldukça önem kazanmaktadır. Özellikle Almanca öğretmeni yetiştirme sürecinde Almanca öğretmenliği programındaki öğretmen adayları aslında hedef olarak gördüğü İngilizce öğretmenliği programı için üniversite sınavından yeterli dil puanını alamayıp zorunlu olarak Almanca öğretmenliği programına yerleşmek durumunda kalan öğretmen adaylarıdır. Bu programı kazanmaları sonucu zorunlu olarak da iki dönem hazırlık sınıfında Almancayı en iyi şekilde öğrenmeleri ve B2 düzeyinde tamamlamaları beklenmektedir. Hazırlık sınıfı sonrası alınan 4 yıllık lisans eğitimleri boyunca da Alman dilinde kendilerini geliştirmiş olmaları mesleklerini başarı ile gerçekleştirmeleri için kaçınılmazdır. Bu bağlamda meslek olarak seçtikleri öğretmenliğe yönelik tutumları ve alan olarak seçtikleri Alman diline karşı motivasyonları daha nitelikli Almanca öğretmeni olma açısından önemli bir durum olarak kendini göstermektedir.

Geleceğimizi yönlendirecek öğrencilerin yetiştirilmesinde oldukça önemli bir role sahip olan öğretmen adaylarının mesleklerine karşı tutumları ve alan seçimindeki motivasyon durumlarının incelenip değerlendirmeye alınması ve görevlerine bu özelliklerini bilerek başlamaları önem taşımaktadır. Öğretmen adaylarının tutum ve motivasyonlarına ilişkin çalışmaların nitelikli öğretmen yetişme açısından önemli katkılar sağlayacağı düşünülmektedir. Bu çalışmanın da amacı yabancı dil Almanca öğretmen adaylarının "Öğretmenlik Mesleğine Yönelik Tutum" ile "Meslek Alan Seçimindeki Motivasyonları" ilişkisini belirlemektir. Bu nedenle şu sorulara yanıt aranmıştır.

• Yabancı dil Almanca öğretmen adaylarının “Öğretmenlik Mesleğine Yönelik Tutum” ve "Meslek Alan Seçimindeki Motivasyon”ları hangi düzeydedir?

- Yabancı dil Almanca öğretmen adaylarının "Öğretmenlik Mesleğine Yönelik Tutum”ları ile "Meslek Alan Seçimindeki Motivasyon"ları

\section{a. cinsiyet}

b. öğrenim gördükleri sınıf değişkenine göre farklılaşmakta mıdır?

- Yabancı dil öğretmen adaylarının meslek ve alan seçiminde etkili olan "içsel" ve "dışsal" nedenlerin etki düzeyine ilişkin görüşleri nelerdir?

Bu görüşleri

\section{a. cinsiyet}

b. öğrenim gördükleri sınıf değişkenine göre farklılaşmakta mıdır?

\section{Yöntem}

Adayların öğretmenlik mesleğine yönelik tutumları ile meslek alan seçimindeki motivasyonları gibi iki değişkenin arasındaki değişimi ya da bu değişimin derecesini ortaya çıkarmayı sağlayan ilişkisel tarama modelinin kullanıldığı bu araştırmada, ilişkiler ilişkisel çözümleme korelasyonel ve karşılaştırma yapılarak elde edilmiştir (Karasar, 2008).

Araştırmanın bağımlı değişkenleri, meslek alan seçme motivasyon ölçeğinin iki alt boyutu (içsel ve dışsal), bağımsız değişkeni de öğretmenlik mesleğine yönelik tutumlarıdır.

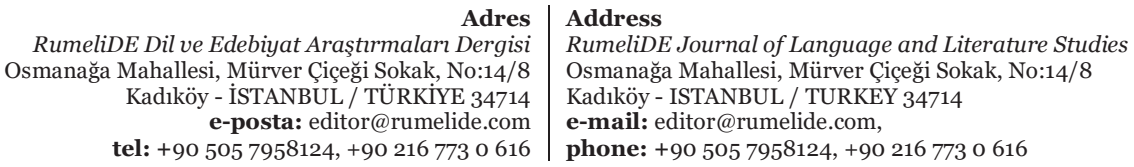


800 / RumeliDE Journal of Language and Literature Studies 2022.26 (February)

The relationship between German pre-service teachers' attitudes towards teaching profession and their motivation on profession choice / Ş. Çelikkaya (pp. 795-813)

\section{Örneklem}

Araştırma, 2020-2021 eğitim öğretim yılı Anadolu Üniversitesi Eğitim Fakültesi Yabancı Diller Eğitimi Bölümü Almanca Öğretmenliği Programının her sınıf düzeyindeki öğretmen adayları ile yürütülmüsstür. Örneklemin belirlenmesinde, basit seçkisiz örnekleme tekniği kullanılmış ve araştırmanın örneklemi toplam $113(\mathrm{~N})$ öğretmen adayıdır. Örneklemin demografik bilgilerine bakıldığında araştırmaya katılan öğretmen adaylarının 79 'unun ( $\bar{x}$ 121.76, Ss 11.366) kadın, 34 'ünün ( $\bar{x} 118.24$, Ss 12.502) ise erkek olduğu görülmektedir. Ayrıca öğretmen adaylarının 18 ile 27 yaş aralığında oldukları sonucuna ulaşılmıştır.

Araştırma kapsamında kullanılan veri toplama araçları 113 öğretmen adayına Covid-19 nedeniyle online uygulanmıştır. İnceleme sonucunda, ölçek maddelerinin tamamının doldurulduğu, boş bırakılan herhangi bir verinin olmadığı gözlemlenmiştir.

\section{Veri toplama araçları}

Ölçeğin birinci bölümünde, araştırmada yer alan öğretmen adaylarının cinsiyet, sınıf ve yaş aralığı gibi demografik bilgileri; ikinci bölümünde ise, "Meslek Alan Seçme Motivasyonu Ölçeği” ve "Öğretmenlik Mesleğine Yönelik Tutum Ölçeği” yer almaktadır.

Meslek ve alan seçiminde motivasyon düzeylerini ölçebilmek amacıyla adaylara; Mayr (1998) tarafından geliştirilip, Türkçeye de Atav ve Altunoğlu (2013) tarafından uyarlanan "Meslek ve Alan Seçiminde Motivasyon Ölçeği”" kullanılmıştır. 5'li Likert tipindeki ölçek, "İçsel ve Dışsal meslek seçim nedenleri” ve "İçsel alan ve Dişsal alan seçim nedenleri" şeklinde dört alt boyuttan ve toplam 21 ifadeden oluşmaktadır. Ölçekte yer alan maddeler meslek ve alan seçmenin önemlilik düzeyine göre "çok önemli" (5)’ten ve "hiç önemli değil” (1) e kadar derecelendirilmiştir.

Öğretmenlik mesleğine karşı tutumları ortaya çıarmak amacıyla adaylara Üstüner’in (2006) geliştirmiş olduğu "Öğretmenlik Mesleğine Yönelik Tutum Ölçeği” uygulanmıştır. Bu ölçek, 5’li Likert tipinde ve 34 madde olarak desenlenmiştir. Tutum ifadelerinde 5 olumlu tutumu 1 ise olumsuz tutumu ifade etmiştir.

\section{Veri analizi}

Araştırmanın verileri SPSS (Statistical Package for the Social Sciences) programı ile çözümlenmiştir. Verilerin analizinde betimsel istatistik yöntemlerinden aritmetik ortalama, standart sapma, Pearson korelasyon katsayısı kullanılmış ve iki yönlü varyans analizi (ANOVA) yapılmıştır.

\section{Bulgular}

Bu çalışmanın amacı, yabancı dil Almanca öğretmenliği programı öğretmen adaylarının meslek alan seçimi motivasyonları ve öğretmenlik mesleğine yönelik tutumları arasında manidar bir ilişkinin var olup olmadığını ortaya koymaktır. Bu nedenle birinci sınıftan dördüncü sınıfa kadar tüm Almanca öğretmenliği programı adaylarının meslek alan seçimi motivasyon ve mesleğe yönelik tutum ölçeklerinden aldıkları puanlar üzerinde korelasyon analizi yapılmıştır. Adayların meslek alan seçimi motivasyon ve mesleğe yönelik tutum ölçeklerinden aldıkları puanlar aşă̆ıda Tablo 1. de gösterilmiştir.

\footnotetext{
Adres $\mid$ Address

RumeliDE Dil ve Edebiyat Araşttrmaları Dergisi Osmanağa Mahallesi, Mürver Çiçeği Sokak, No:14/8 Kadıköy - İSTANBUL / TÜRKIYE 34714 e-posta: editor@rumelide.com

RumeliDE Journal of Language and Literature Studies Osmanağa Mahallesi, Mürver Çiçeği Sokak, No:14/8 Kadıköy - ISTANBUL / TURKEY 34714

e-mail: editor@rumelide.com tel: +90 5057958124, +902167730616 phone: +90 5057958124, +90 2167730616
} 
RumeliDE Dil ve Edebiyat Araştırmaları Dergisi 2022.26 (Şubat)/ 801 Almanca öğretmen adaylarını öğretmenlik mesleğine yönelik tutumları ile meslek alan seçimindeki motivasyonları arasındaki ilişki / Ș. Çelikkaya (795-813. s.)

Tablo 9. Öğretmenlik mesleğine yönelik tutum ve meslek alan seçimi motivasyon puanları

\begin{tabular}{llll}
\hline & $\mathrm{x}$ & $\mathrm{Ss}$ & $\mathrm{N}$ \\
\hline Tutum & 120.70 & 11.775 & 113 \\
Motivasyon & 75.96 & 12.848 & 113 \\
\hline
\end{tabular}

Tablo 1.de gösterilen puanlar arasında ilişki olup olmadığını bulmak için Pearson Korelasyon analizinin sonuçları Tablo 2.de gösterilmiştir.

Tablo 10. Öğretmenlik mesleğine yönelik tutum ve meslek alan seçimi motivasyon arasındaki korelasyon sonucu

\begin{tabular}{llll}
\hline & $\mathrm{N}$ & $R$ & $P$ \\
\hline Tutum & 113 & $.618^{* *}$ & .000 \\
Motivasyon & &. & \\
\hline
\end{tabular}

**. Korelasyon o.01 seviyesinde anlamlıdır.

Tablo 2. de görülebileceği üzere Almanca öğretmenliği programı öğretmen adaylarının öğretmenlik mesleğine yönelik tutum $(\overline{\mathrm{x}}=120.7, s s=11.77)$ ve meslek alan seçimi motivasyon $(\overline{\mathrm{x}}=75.9, s s=12.84)$ puanları arasında olumlu yönde güçlü ve manidar bir ilişki bulunmaktadır $(r<.001)$. Bu sonuçlar göstermektedir ki, adayların öğretmenlik mesleğine yönelik tutum puanları ne kadar yüksekse, meslek alan seçim motivasyon puanları da o kadar yüksektir. Aynı şekilde, düşük tutum puanları, düşük motivasyon puanları anlamına gelmektedir.

Çalışmanın diğer amacı ise cinsiyet ve eğitim görülen sınıf değişkelerinin öğretmenlik mesleğine yönelik tutum, meslek alan seçim motivasyonu, içsel/dışsal alan seçim, içsel/dışsal meslek seçim puanları üzerinde etkisinin olup olmadığını ortaya çıkarmaktır. Bu bağlamda adayların her bir değişken için elde ettiği puanlar üzerinde iki yönlü 2 (kadın-erkek)* 4 (1.-4. Sınıf) ANOVA analizi yapılmıştır.

Tablo 3. Öğretmenlik mesleğine yönelik tutum puanlarının cinsiyete ve sınıflara göre dağılımı

\begin{tabular}{|c|c|c|c|c|}
\hline & Sinif & $\bar{x}$ & Ss & $\mathrm{N}$ \\
\hline \multirow[t]{5}{*}{ Erkek } & 1. Sinıf & 118.33 & 7.616 & 9 \\
\hline & 2. Sinıf & 119.71 & $15 \cdot 510$ & 7 \\
\hline & 3. Sinıf & 121.60 & 7.947 & 10 \\
\hline & 4. Sinıf & 112.63 & 18.134 & 8 \\
\hline & Toplam & 118.24 & 12.502 & 34 \\
\hline \multirow[t]{5}{*}{ Kadın } & 1. Sinıf & 122.94 & 9.890 & 17 \\
\hline & 2. Sinıf & 120.11 & 13.788 & 19 \\
\hline & 3. Sinıf & $117 \cdot 30$ & 11.494 & 20 \\
\hline & 4. Sinıf & 126.13 & 8.704 & 23 \\
\hline & Toplam & 121.76 & 11.366 & 79 \\
\hline \multirow[t]{4}{*}{ Toplam } & 1. Sinif & 121.34 & 9.28 & 26 \\
\hline & 2. Sinıf & 120 & 13.95 & 26 \\
\hline & 3. Sinıf & 118.73 & 10.5 & 30 \\
\hline & $\begin{array}{r}\text { RumeliDE Dil } \\
\text { Osmanağa Mahal } \\
\text { Kadıl } \\
\text { tel: }+9\end{array}$ & $\begin{array}{r}\text { Adres } \\
\text { at Araşttrmalar Dergisi } \\
\text { er Çiçeği Sokak, No:14/8 } \\
\text { NBUL / TÜRKIYE 34714 } \\
\text { a: editor@rumelide.com } \\
8124,+90216773 \text { o } 616\end{array}$ & \multicolumn{2}{|c|}{$\begin{array}{l}\text { Address } \\
\text { RumeliDE Journal of Language and Literature Studies } \\
\text { Osmanağa Mahallesi, Mürver Çiçeği Sokak, No:14/8 } \\
\text { Kadıköy - ISTANBUL / TURKEY } 34714 \\
\text { e-mail: editor@rumelide.com, } \\
\text { phone: +90 505 7958124, +90 } 216773 \text { o } 616\end{array}$} \\
\hline
\end{tabular}


802 / RumeliDE Journal of Language and Literature Studies 2022.26 (February)

The relationship between German pre-service teachers' attitudes towards teaching profession and their motivation on profession choice / Ş. Çelikkaya (pp. 795-813)
4. Sinif
122.9
13.11
31

Tablo 3.'te adayların mesleğe yönelik tutum puanlarının cinsiyet ve sinıflara göre dağılımının ortalamaları ve standart sapmaları gösterilmektedir. Adayların öğretmenlik mesleğine yönelik tutum puanlarının cinsiyet ve sınıfa göre fark gösterip göstermediğini bulmak amacıyla iki yönlü ANOVA analizi yapılmıştır. Bu analizin sonuçları Tablo 4'de gösterilmiştir.

Tablo 4. Öğretmenlik mesleğine yönelik tutum puanları üzerinde yapılan iki yönlü ANOVA analizi sonucu

\begin{tabular}{llllll}
\hline & KT & sd & KO & F & $p$. \\
\hline Cinsiyet & 295.014 & 1 & 295.014 & 2.222 & .139 \\
Sinıf & 24.176 & 3 & 8.059 & .061 & .980 \\
Cinsiyet * Sinıf & 1056.292 & 3 & 352.097 & 2.652 & .053 \\
Hata & 13941.243 & 105 & 132.774 & & \\
Toplam & 1661745.000 & 113 & & & \\
Düzeltilmiş Toplam & 15529.770 & 112 & & & \\
\hline
\end{tabular}

Tablo 4.'te görülebileceği üzere erkek adayların öğretmenlik mesleğine yönelik tutum puanları ( $\overline{\mathrm{x}}=118.24, S S=12.5)$ ile kadın adayların öğretmenlik mesleğine yönelik tutum puanları ( $\overline{\mathrm{x}}=121.76$, $S S=11.36)$ arasında kadınların lehine ufak bir fark vardır fakat bu fark istatistiksel olarak anlamlı bir fark değildir $(F(1,105)=2.222, p>$..05). Elde edilen veriler göre de cinsiyetin öğretmenlik mesleğine yönelik tutum puanları üzerinde etkisinin olmadığını göstermektedir.

Benzer şekilde birinci ( $\overline{\mathrm{x}}=121.34, S S=9.28)$, ikinci ( $\overline{\mathrm{x}}=120, S S=13.95)$, üçüncü ( $\overline{\mathrm{x}}=118.73, S S=10.5)$ ve dördüncü ( $\bar{x}=122.9, S S=13.11)$ sinıfta bulunan adayların mesleğe yönelik tutum puanları arasında bulunan farkların da istatiksel olarak anlamlı olmadığı görülmektedir $(F(3,105)=.061, p>.05)$. Bu sonuç da içinde bulunulan sınıf seviyesinin mesleğe yönelik tutumda anlamlı bir etkinin olmadığını göstermektedir.

Aynı şekilde, cinsiyet ve eğitim görülen sınıf değişkenleri meslek alan seçim motivasyon puanları üzerinde etkisi olup olmadığı da çalışmanın kapsamı içerisinde ele alınmıştır. Bu bağlamda, adayların meslek alan seçim motivasyon puanları üzerinde iki yönlü ANOVA analizi yapılmış, sonuçlar Tablo 5.'te gösterilmiştir.

Tablo 5. Meslek alan seçimi motivasyon puanlarının cinsiyete ve sınıflara göre dağılımı

\begin{tabular}{lllll}
\hline & Sinif & $\bar{x}$ & Ss & N \\
\hline Erkek & 1. Sinif & 68.89 & 14.075 & 9 \\
& 2. Sinif & 80.57 & 11.545 & 7 \\
& 3. Sinif & 79.20 & 9.762 & 10 \\
& 4. Sinif & 72.00 & 19.698 & 8 \\
& Toplam & 75.06 & 14.312 & 34 \\
\hline Kadin & 1. Sinif & 75.71 & 12.544 & 20 \\
& 2. Sinif & 78.00 & 13.068 & 20
\end{tabular}

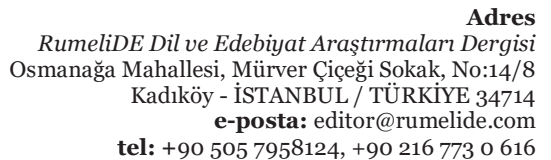

Adres isi RumeliDE Journal of Language and Literature Studies Osmanağa Mahallesi, Mürver Çiçeği Sokak, No:14/8 Kadıköy - ISTANBUL / TURKEY 34714 e-mail: editor@rumelide.com, phone: +90 5057958124, +90 2167730616 
RumeliDE Dil ve Edebiyat Araştırmaları Dergisi 2022.26 (Şubat)/ 803 Almanca öğretmen adaylarının öğretmenlik mesleğine yönelik tutumları ile meslek alan seçimindeki motivasyonları arasındaki ilişki / Ș. Çelikkaya (795-813. s.)

\begin{tabular}{lllll} 
& 4. Sinif & 77.87 & 12.621 & 23 \\
Toplam & 76.34 & 12.242 & 79 \\
\hline 1. Sinif & 73.35 & 13.230 & 26 \\
& 2. Sinif & 78.69 & 12.502 & 26 \\
& 3. Sinif & 75.43 & 10.820 & 30 \\
& 4. Sinif & 76.35 & 14.635 & 31 \\
\hline
\end{tabular}

Meslek Alan Seçim Motivasyon Puanları Üzerinde Yapılan İki Yönlü ANOVA Analizi Sonucu Tablo 6.'da sunulmuştur.

Tablo 6. Meslek alan seçim motivasyon puanlari üzerinde yapilan iki yönlü ANOVA analizi sonucu

\begin{tabular}{llllll}
\hline & KT 1 & sd & KO & F & p. \\
\hline Cinsiyet & 29.152 & 1 & 29.152 & .176 & .676 \\
Sinıf & 561.154 & 3 & 187.051 & 1.130 & .340 \\
Cinsiyet * Sinıf & 699.918 & 3 & 233.306 & 1.410 & .244 \\
Hata & 17379.291 & 105 & 165.517 & & \\
Toplam & 670417.000 & 113 & & & \\
Düzeltilmiş Toplam & 18488.779 & 112 & & & \\
\hline
\end{tabular}

Tablo 6.'da görüldüğü gibi erkek adayların meslek alan seçim motivasyon puanları ( $\bar{x}=75.06, S S=14.31)$ ile kadın adayların motivasyon puanları $(\overline{\mathrm{x}}=76.34, S S=12.24)$ arasında kadınların lehine küçük bir farklılık olsa da, istatistiksel olarak bu farklılık anlamlı değildir $(F(1,105)=.176, p>.05)$. Bu da meslek alan seçim motivasyon puanları üzerinde cinsiyet faktörünün belirleyici olmaktan uzak olduğunu göstermektedir. Benzer şekilde birinci sınıf ( $\bar{x}=73.35, S S=13.23$ ), ikinci $\operatorname{sinıf}(\bar{x}=78.69, S S=12.5)$, üçüncü sinıf ( $\bar{x}=75.43, S S=10.82)$, ve dördüncü sinıf $(\bar{x}=76.35, S S=14.63)$ adaylarının motivasyon düzeyleri arasında gözlemlenen farkların da istatistiksel olarak anlamlı olmadığı ortaya çımıştır $(F(3,105)=1.130$, $p>.05)$. Bu da sınıf derecesinin meslek alan seçim motivasyon üzerinde anlamlı bir etkisi olmadığını göstermektedir.

Çalışmada aynı zamanda içsel alan seçim puanlarının cinsiyet ve sınıfa göre değişimi de incelenmiştir. Elde edilen puanların dağılımı Tablo 7.'de gösterilmiştir.

Tablo 7. İçsel alan seçim puanlarının cinsiyete ve sinıflara göre dağılımı

\begin{tabular}{lllll}
\hline Cinsiyet & Sinif & $\bar{x}$ & Ss & N \\
\hline Erkek & 1. Sinif & 11.44 & 2.698 & 9 \\
& 2. Sinif & 13.57 & 2.149 & 7 \\
& 3. Sinif & 13.80 & 1.317 & 10 \\
& 4. Sinif & 11.88 & 2.357 & 8 \\
& Toplam & 12.68 & 2.319 & 34 \\
\hline Kadın & 1. Sinif & 12.76 & 2.386 & 17 \\
& 2. Sinif & 13.32 & 1.857 & 19 \\
& 3. Sinif & 12.95 & 1.538 & 20 \\
\hline
\end{tabular}

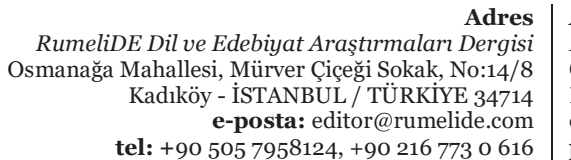

dres | Address

RumeliDE Journal of Language and Literature Studies

Osmanağa Mahallesi, Mürver Çiçeği Sokak, No:14/8

Kadıköy - ISTANBUL / TURKEY 34714

-mail: editor@rumelide.com,

phone: +90 $5057958124,+902167730616$ 
804 / RumeliDE Journal of Language and Literature Studies 2022.26 (February)

The relationship between German pre-service teachers' attitudes towards teaching profession and their motivation on profession choice / Ş. Çelikkaya (pp. 795-813)

\begin{tabular}{lllll} 
& 4. Sinif & 12.96 & 2.884 & 23 \\
\hline Toplam & 13.00 & 2.219 & 79 \\
\hline & 1. Sinif & 12.31 & 2.526 & 26 \\
& 2. Sinif & 13.38 & 1.899 & 26 \\
& 3. Sinif & 13.23 & 1.501 & 30 \\
& 4. Sinif & 12.68 & 2.761 & 31 \\
\hline
\end{tabular}

Adayların içsel alan seçim puanlarının cinsiyet ve sınıfa göre farklılıklarını bulmak amacıyla yapılan iki yönlü ANOVA analizi sonuçları da Tablo 8.'de gösterilmiştir.

Tablo 8. İçsel alan seçim puanları üzerinde yapılan iki yönlü ANOVA analizi sonucu

\begin{tabular}{llllll}
\hline & KT & Sd & KO & F & $p$ \\
\hline Cinsiyet & 2.456 & 1 & 2.456 & .495 & .483 \\
Sinıf & 32.085 & 3 & 10.695 & 2.153 & .098 \\
Cinsiyet * Sinıf & 20.146 & 3 & 6.715 & 1.352 & .262 \\
Hata & 521.482 & 105 & 4.966 & & \\
Toplam & 19376.000 & 113 & & & \\
Düzeltilmiş Toplam & 563.929 & 112 & & & \\
\hline
\end{tabular}

Yapılan iki yönlü ANOVA sonucunda erkek adayların içsel alan seçim puanları $(\bar{x}=12.68, S S=2.31)$ ile kadın adayların içsel alan seçim puanları $(\bar{x}=13, S S=2.21)$ arasında gözlemlenen farkın anlamlı olmadığ ortaya çıkmıştır $(F(1,105)=.495, p>.05)$. Buradan yola çlkarak cinsiyetin içsel alan seçim puanları üzerinde anlamlı bir etkisi olmadığı sonucuna varılmaktadır. Yine, benzer şekilde, içinde bulunulan sınıf bazında bakıldığında; birinci sınıf ( $\bar{x}=12.31, S S=2.52)$, ikinci sinıf $(\bar{x}=13.38, S S=1.89)$, üçüncü sinıf $(\bar{x}=13.23, S S=1.5)$, ve dördüncü sınıf $(\bar{x}=12.68, S S=2.76)$ adayları arasında gözlemlenen farkların da anlamlı olmadığı bulgular arasındadır $(F(3,105)=2.153, p>.05)$. Bu da içinde bulunulan sınıfın içsel alan seçim puanları üzerinde önemli bir fark yaratmadığı sonucunu ortaya çıarmaktadır.

Dışsal alan seçim puanları üzerinde cinsiyet ve içinde bulunulan sınıfın etkisini saptamak da bu çalışmanın amaçları arasındadır. Tablo 9.'da dışsal alan seçim puanlarının cinsiyet ve sınıflara göre dağ 1 lımı verilmiştir.

Tablo 9. Dışsal alan seçim puanlarının cinsiyete ve sınıflara göre dağılımı

\begin{tabular}{|c|c|c|c|c|}
\hline & Sinif & $\bar{x}$ & SS & $\mathrm{N}$ \\
\hline \multirow[t]{5}{*}{ Erkek } & 1. Sinif & 13.44 & 6.598 & 9 \\
\hline & 2. Sinif & 16.86 & $5 \cdot 728$ & 7 \\
\hline & 3. Sinif & 17.00 & 6.254 & 10 \\
\hline & 4. Sinif & 16.13 & 6.151 & 8 \\
\hline & Toplam & 15.82 & 6.117 & 34 \\
\hline \multirow[t]{4}{*}{ Kadın } & 1. Sinif & 16.12 & 5.776 & 17 \\
\hline & 2. Sinif & 15.89 & $5 \cdot 322$ & 19 \\
\hline & 3. Sinif & 14.65 & $5 \cdot 75^{2}$ & 20 \\
\hline & $\begin{array}{r}\text { RumeliDE Dil } \\
\text { Osmanağa Mahall } \\
\text { Kadık } \\
\text { tel: }+9\end{array}$ & $\begin{array}{r}\text { Adres } \\
\text { Araşttrmaları Dergisi } \\
\text { Çiçeği Sokak, No:14/8 } \\
\text { 3UL / TÜRKIYY } 34714 \\
\text { editor@rumelide.com } \\
24,+90216773 \text { o } 616\end{array}$ & \multicolumn{2}{|c|}{$\begin{array}{l}\text { Address } \\
\text { RumeliDE Journal of Language and Literature Studies } \\
\text { Osmanağa Mahallesi, Mürver Ciçeği Sokak, No:14/8 } \\
\text { Kadıköy - ISTANBUL / TURKEY } 34714 \\
\text { e-mail: editor@rumelide.com, } \\
\text { phone: + }+90505 \text { 7958124, +90 } 216773 \text { o } 616\end{array}$} \\
\hline
\end{tabular}


RumeliDE Dil ve Edebiyat Araştırmaları Dergisi 2022.26 (Şubat)/ 805 Almanca öğretmen adaylarını öğretmenlik mesleğine yönelik tutumları ile meslek alan seçimindeki motivasyonları arasındaki ilişki / Ş. Çelikkaya (795-813. s.)

\begin{tabular}{lllll} 
& 4. Sinif & 15.35 & 4.599 & 23 \\
& Toplam & 15.47 & 5.264 & 79 \\
\hline Total & 15.19 & 6.080 & 26 \\
& 2. Sinif & 16.15 & 5.334 & 26 \\
& 3. Sinif & 15.43 & 5.923 & 30 \\
& 4. Sinif & 15.55 & 4.945 & \multicolumn{2}{c}{31} \\
\hline
\end{tabular}

Adayların dışsal alan seçim puanlarının cinsiyet ve sınıflara göre dağılımındaki farklılığı bulabilmek için yapılan iki yönlü ANOVA analizi sonuçları Tablo 10.'da gösterilmiştir.

Tablo 1o. Dışsal alan seçim puanları üzerinde yapılan iki yönlü ANOVA analizi sonucu

\begin{tabular}{llllll}
\hline & KT & Sd & KO & F & $p$ \\
\hline Cinsiyet & 2.933 & 1 & 2.933 & .093 & .761 \\
Sinıf & 29.537 & 3 & 9.846 & .313 & .816 \\
Cinsiyet * Sinıf & 83.390 & 3 & 27.797 & .885 & .452 \\
Hata & 3299.276 & 105 & 31.422 & & \\
Toplam & 30812.000 & 113 & & & \\
Düzeltilmiş Toplam & 3399.611 & 112 & & & \\
\hline
\end{tabular}

Yapılan iki yönlü ANOVA sonucunda erkek adayların dışsal alan seçim puanları ile ( $\bar{x}=15.82, S S=6.11)$, kadın adayların dışsal alan puanları ( $\bar{x}=15.47, S S=5.26)$ arasındaki küçük farkın anlamlı olmadığı ortaya çlkmıştır $(F(1,105)=.093, p>.05)$. Bu sonuçla cinsiyetin dışsal alan seçim puanları üzerinde önemli bir etkiye sahip olmadığı bulunmuştur. Benzer şekilde sinıflar açısından bakıldığında birinci ( $\bar{x}=15.19$, $S S=6.08)$, ikinci ( $\overline{\mathrm{x}}=16.15, S S=5.33)$, üçüncü ( $\overline{\mathrm{x}}=15.43, S S=5.92)$, ve dördüncü ( $\overline{\mathrm{x}}=15.55, S S=4.94)$ sinıflar arasındaki farkların da anlamlı olmadığı görülmüștür $(F(3,105)=.313, p>.05)$.

Adayların içsel meslek seçim puanlarının cinsiyet ve sınıf bazında farklar gösterip göstermediği de bu çalışma kapsamında ele alınmıştır. İçsel meslek seçim puanlarının cinsiyet ve sınıf bazında dağılımı Tablo 11.'de görselleştirilmiştir.

Tablo 11. İçsel meslek seçim puanlarının cinsiyete ve sınıflara göre dağılımı

\begin{tabular}{|c|c|c|c|c|}
\hline & Sinif & $\bar{x}$ & Ss & $\mathrm{N}$ \\
\hline \multirow[t]{5}{*}{ Erkek } & 1. Sinif & 30.22 & 6.438 & 9 \\
\hline & 2. Sinif & 35.86 & 3.625 & 7 \\
\hline & 3. Sinif & 32.00 & $3 \cdot 528$ & 10 \\
\hline & 4. Sinıf & 33.50 & 9.426 & 8 \\
\hline & Toplam & 32.68 & 6.227 & 34 \\
\hline \multirow[t]{6}{*}{ Kadın } & 1. Sinif & 32.06 & 5.815 & 17 \\
\hline & 2. Sinif & 34.79 & 5.442 & 19 \\
\hline & 3. Sinif & 32.40 & 6.082 & 20 \\
\hline & 4. Sinıf & 34.78 & 5.977 & 23 \\
\hline & Toplam & 33.59 & 5.874 & 79 \\
\hline & \multicolumn{2}{|r|}{$\begin{array}{r}\text { Adres } \\
\text { Araşttrmaları Dergisi } \\
\text { Çiçeği Sokak, No:14/8 } \\
\text { 3UL / TÜRKIYE } 34714 \\
\text { editor@rumelide.com } \\
124,+90216773 \text { o } 616\end{array}$} & \multicolumn{2}{|c|}{$\begin{array}{l}\text { Address } \\
\text { RumeliDE Journal of Language and Literature Studies } \\
\text { Osmanağa Mahallesi, Mürver Çiceği Sokak, No:14/8 } \\
\text { Kadıköy - ISTANBUL / TURKEY } 34714 \\
\text { e-mail: editor@rumelide.com, } \\
\text { phone: +90 505 7958124, +90 } 216773 \text { o } 616\end{array}$} \\
\hline
\end{tabular}


806 / RumeliDE Journal of Language and Literature Studies 2022.26 (February)

The relationship between German pre-service teachers' attitudes towards teaching profession and their motivation on profession choice / Ş. Çelikkaya (pp. 795-813)

\begin{tabular}{|c|c|c|c|c|}
\hline \multirow[t]{4}{*}{ Toplam } & 1. Sinif & 31.42 & 5.974 & 26 \\
\hline & 2. Sinif & 35.08 & 4.971 & 26 \\
\hline & 3. Sinif & 32.27 & $5 \cdot 304$ & 30 \\
\hline & 4. Sinif & 34.45 & 6.874 & 31 \\
\hline
\end{tabular}

İçsel meslek seçim puanlarının cinsiyet ve sınıflara göre farklılık gösterip göstermediği, yapılan iki yönlü ANOVA analizi yoluyla saptanmıştır. Analizin sonuçları Tablo 12.'de gösterilmiştir.

Tablo 12. İçsel meslek seçim puanları üzerinde yapılan iki yönlü ANOVA analizi sonucu

\begin{tabular}{llllll}
\hline & KT & Sd & KO & F & $p$ \\
\hline Cinsiyet & 8.788 & 1 & 8.788 & .249 & .619 \\
Sinıf & 238.864 & 3 & 79.621 & 2.255 & .086 \\
Cinsiyet * Sinıf & 26.167 & 3 & 8.722 & .247 & .863 \\
Hata & 3707.225 & 105 & 35.307 & & \\
Toplam & 129435.000 & 113 & & & \\
Düzeltilmiş Toplam & 3990.531 & 112 & & & \\
\hline
\end{tabular}

İçsel meslek seçim puanlarının erkek $(\overline{\mathrm{x}}=32.68, S S=6.22)$ ve kadın adaylar $(\overline{\mathrm{x}}=33.59, S S=5.87)$ bakımından dağılımı arasında anlamlı bir fark gözlenmemiştir $(F(1,105)=.249, p>.05)$. Bu sonuçla, cinsiyetin içsel meslek seçim puanları üzerinde önemli bir etkiye sahip olmadığı ortaya çıarılmıştır. Yine benzer şekilde sinfflar bazında birinci $(\bar{x}=31.42, S S=5.97)$, ikinci $(\bar{x}=35.08, S S=4.97)$, üçüncü ( $\overline{\mathrm{x}}=3.27, S S=5.30)$, ve dördüncü ( $\overline{\mathrm{x}}=34.45, S S=6.87)$ sinıflar arasında gözlenen farkların da anlamlı olmadığı görülmüştür $(F(3,105)=2.255, p>.05)$. Bu sonuç da sınıfın içsel meslek seçim puanlarını belirlemede etkili bir faktör olmadığını göstermektedir.

Adayların dışsal meslek seçim puanlarının cinsiyet ve sınıflara göre dağılımı incelenmiştir. Dışsal meslek seçim puanlarının bu iki değişkene göre dağılımı Tablo 13.'te verilmiştir.

Tablo 13. Dışsal meslek seçim puanlarının cinsiyete ve sınıflara göre dağılımı

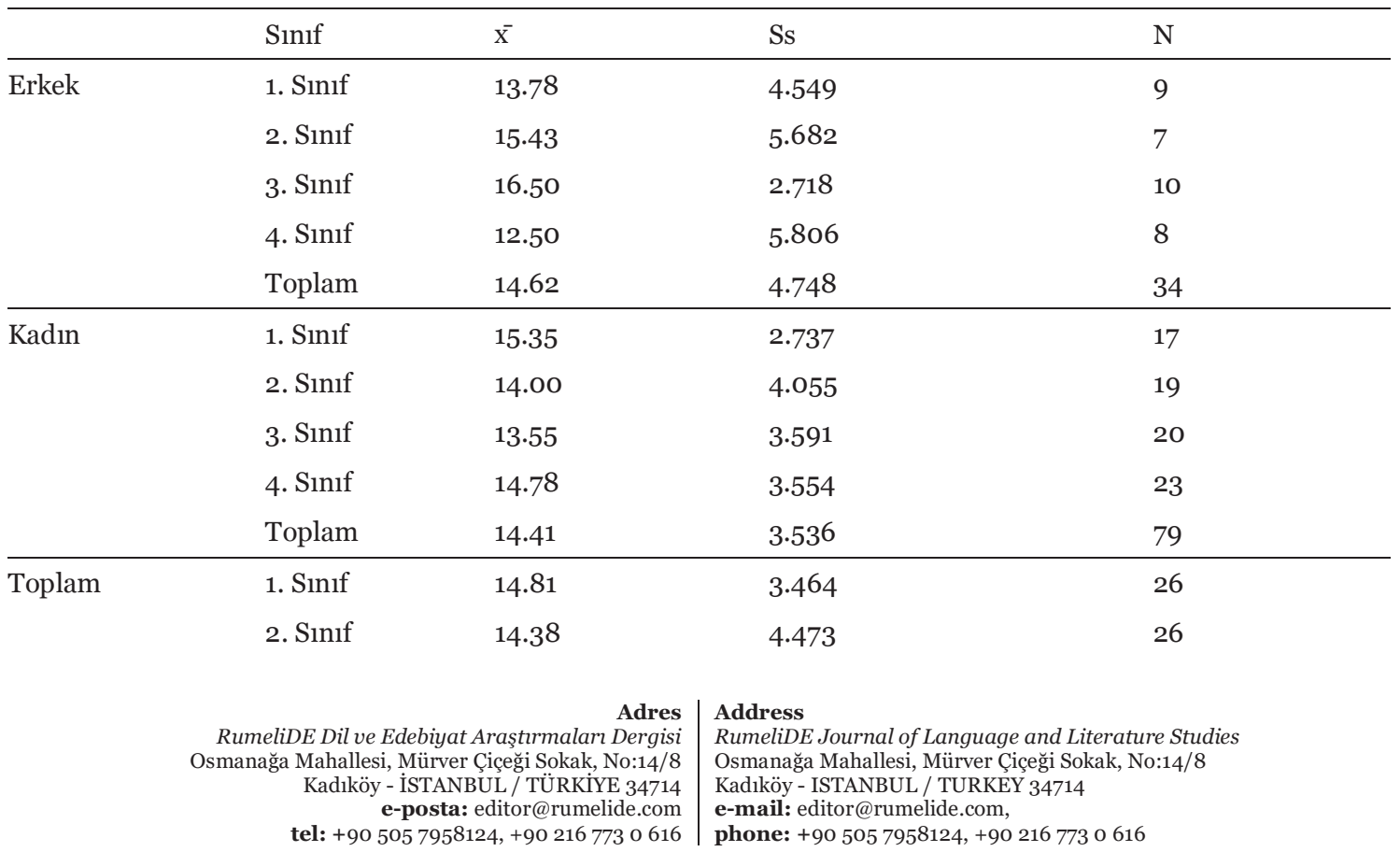


RumeliDE Dil ve Edebiyat Araştırmaları Dergisi 2022.26 (Şubat)/807 Almanca öğretmen adaylarını öğretmenlik mesleğine yönelik tutumları ile meslek alan seçimindeki motivasyonları arasındaki ilişki / Ș. Çelikkaya (795-813. s.)

\begin{tabular}{llll} 
3. Sinif & 14.53 & 3.569 & 30 \\
4. Sinif & 14.19 & 4.262 & 31 \\
\hline
\end{tabular}

Son olarak da iki yönlü ANOVA analizi ile adayların dışsal meslek puanlarının cinsiyet ve sınıf bazında dağılımında önemli farklar olup olmadığı incelenmiş ve analizin sonuçları Tablo 14.'te gösterilmiştir.

Tablo 14. Dişsal meslek puanları üzerinde yapılan iki yönlü ANOVA analizi sonucu

\begin{tabular}{llllll}
\hline & KT & sd & KO & F & $P$ \\
\hline Cinsiyet & .397 & 1 & .397 & .026 & .872 \\
Sinıf & 25.894 & 3 & 8.631 & .566 & .638 \\
Cinsiyet * Sinıf & 113.250 & 3 & 37.750 & 2.477 & .065 \\
Hata & 1600.515 & 105 & 15.243 & & \\
Toplam & 25377.000 & 113 & & & \\
Düzeltilmiş Toplam & 1720.142 & 112 & & & \\
\hline
\end{tabular}

Yapılan iki yönlü ANOVA analizi sonucunda erkek ( $\bar{x}=14.62, S S=4.74)$ ve kadın $(\bar{x}=14.41, S S=3.53)$ adaylar arasında gözlemlenen farkın istatistiksel olarak anlamlı olmadığı bulunmuştur $(F(1,105)=.026$, $p>$.05). Bu da cinsiyet faktörünün dışsal meslek seçim puanları açısından önemli bir faktör olmadığını ortaya koymaktadır. Benzer şekilde sınıf bazında birinci ( $\bar{x}=14.81, S S=3.46)$, ikinci $(\bar{x}=14.38, S S=4.47)$, üçüncü ( $\bar{x}=14.53, S S=3.56)$, ve dördüncü $(\bar{x}=14.19, S S=4.26)$ sinıflar arasında bulunan farkların da anlamlı olmadığı bulunmuştur $(F(3,105)=.566, p>.05)$. Dolayısıyla, sınıf faktörünün de dışsal meslek puanlarını önemli ölçüde etkilemediği ortaya çıkmıştır.

\section{Sonuç}

Yabancı dil Almanca öğretmen adaylarının öğretmenlik mesleğine yönelik tutumları ile meslek alan seçim motivasyonları arasındaki ilişkinin incelendiği bu çalışmada saptanan bulgulara dayalı olarak ortaya çıkan sonuçlar; adayların mesleğe yönelik tutum ve meslek alan seçimi motivasyonlarının arasında olumlu ve anlamlı bir ilişkinin olduğunu göstermektedir. Bu öğretmen adaylarının öğretmenliğe karşı olumlu tutumlarının olması onların mesleğe sahip olmak istediklerini ve bu mesleği kendi istekleriyle tercih ettiklerini göstermektedir. Çünkü büyük fedakârlık ve anlayışlı olmayı gerektiren bu meslekte başarı için bu mesleği sevmek ve isteyerek yapmanın yanı sıra, mesleğe yönelik olumlu tutum ve alan seçimine yönelik olumlu motivasyon içinde olmak da en önemli unsurlardan bir tanesidir (Açışlı ve Kolomuç, 2012). Bu da olumlu tutuma ve alanına yönelik yüksek motivasyona sahip olan öğretmen adaylarının, gelecekte mesleklerini büyük bir istekle, yüksek motivasyon içinde yapacaklarını ve bu sayede de eğitimin kalitesini yükseltme yönünde önemli katkılar sağlayacaklarını göstermektedir. Bu sonuçlar da farklı bölümlerdeki öğretmen adaylarının mesleki tutumlarına karşı yapılmış olan çalışmaların bulgularıyla benzerlik göstermektedir (Küçük, 2007; Alyaz, 2011; Atmaca, 2015).

Mesleğe yönelik cinsiyet değişkenine ait bulgulara bakıldığında erkek öğretmen adayların tutum puanları ile kadın öğretmen adaylarının tutum puanları arasında kadınların lehine ufak bir farklılığın olduğu belirlenmiş ancak bu farklılığın istatistiksel olarak anlamlı olmadığı görülmüştür. Bu da cinsiyetin mesleğe yönelik tutum puanları üzerinde bir etkinin olmadığını göstermektedir. Sınıf değişkenine ilişkin bulgularda ise, birinci sınıftan dördüncü sınıfa kadar tüm adayların mesleklerine

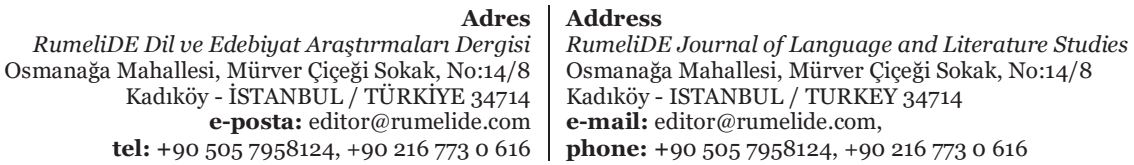


808 / RumeliDE Journal of Language and Literature Studies 2022.26 (February)

The relationship between German pre-service teachers' attitudes towards teaching profession and their motivation on profession choice / Ş. Çelikkaya (pp. 795-813)

yönelik tutum puanlarının sınıf seviyesi üzerinde anlamlı bir etkiye sahip olmadığı sonucunu göstermiştir.

Genel anlamda meslek alan seçim motivasyonlarının incelenmesi ile elde edilen bulgularda kadın adayların meslek alan seçim motivasyonları ile erkek adayların meslek alan seçim motivasyonları arasında büyük bir farklılığın olmadığı ve her ikisinin de motivasyonlarının yüksek düzeyde olduğu belirlenmiştir. Benzer şekilde sınıflar arasında adayların motivasyon düzeylerinde gözlemlenen anlamlı farkların olmadığı ve sınıf seviyesinin meslek alan seçim motivasyon üzerinde anlamlı bir etkisi olmadığı ulaşılan bulgulardandır.

İçsel ve dışsal alan seçim açısından cinsiyete ilişkin bulgular incelendiğinde, büyük oranda anlamlı bir farklılı̆̆ın olmamasına rağmen kadın öğretmen adaylarının içsel alan seçim motivasyonlarının erkek adaylara oranla daha yüksek olduğu, erkek öğretmen adaylarının ise dışsal alan seçim motivasyonlarında kadın adaylara oranla daha yüksek bir algıya sahip oldukları sonucuna ulaşılmıştır.

Çalışmada içsel meslek seçim motivasyonlarında cinsiyete göre çok büyük anlamlı bir farklılık olmamasına rağmen kadın adayların erkek adaylara göre içsel meslek seçim motivasyonlarının (öğretmenlik mesleğinin çok yönlü olması, toplumda önemli bir yer tutması v.b.) az da olsa erkek adaylara oranla daha fazla olduğu görülmektedir. Buna karşılık da erkek adayların dışsal meslek seçim motivasyonları (çalışma saatlerini uygunluğu, iş güvencesi ve çalışmanın serbestlik imkânı v.b) kadın adaylara göre az da olsa daha fazladır. Bu durum kadın adayların öğretmenlik mesleğini daha çok benimseyip, maddi kaygıları fazla önemsemedikleri, mesleki idealizmi daha ön planda tuttukları gibi olumlu bir görüsse sahip oldukları şeklinde yorumlamak mümkündür. Bu da diğer öğretmenlik mesleği alanlarında yapılmış olan çalışmalardaki kadınların erkeklere oranla mesleğe içsel nedenlerle daha fazla tercih ettikleri, daha idealist oldukları bulgularıyla benzerlik göstermektedir (Acat ve Yenilmez, 2004; Özbek, 2007; Özsoy vd., 2010). Bu sonuçların benzerlerine yabancı dil öğrenen öğrencilerle ilgili yapılan araştırmada da ulaşılmıştır (Acat ve Demiral; 2002). Bu sonuçların birbirleri ile benzerlik göstermesi, yabancı dil öğrenme süreciyle öğretmenlik eğitiminin benzer süreçler içerdiğinin bir açıklaması olabileceği gibi, cinsiyetin motivasyonu yönlendirmede farklı bir değişken olabileceğini de akıllara getirebilmektedir.

Özkubat ve Demiriz (2013) de yaptıkları çalışmada içsel motivasyonu yüksek düzeyde olan kişilerin, aktivitelerini istekli ve zevkle yaptıklarını ve içsel motivasyonun bireyin kişisel seçim ve ilgi alanlarıyla ortaya çıktığını belirtmişlerdir. Daha yüksek içsel motivasyona sahip adayların mesleklerini isteyerek, severek ve daha özverili icra edeceklerinin bunun doğal sonucu olarak da iş yaşamında başarılı olacaklarının bir göstergesi olabilir.

Adayların öğretmenlik mesleğine yönelik tutumları ile meslek alan seçim, içsel ve dışsal alan, içsel meslek ve dışsal meslek seçim motivasyonları arasında olumlu yönde bir ilişki saptanmıştır. Bu bulgulara göre, adayların öğretmenlik mesleğine yönelik tutumları olumlu olduğunda meslek alan seçim motivasyonlarının da arttığı söylenebilir. Bunun yanı sıra, adayların mesleğe yönelik tutumları, meslek alan seçim motivasyonunu, içsel ve dışsal alan ve meslek motivasyonlarını da olumlu yönde ve anlamlı düzeyde etkilediği görülmektedir.

Araştırmanın sonuçları kısaca özetlendiğinde;

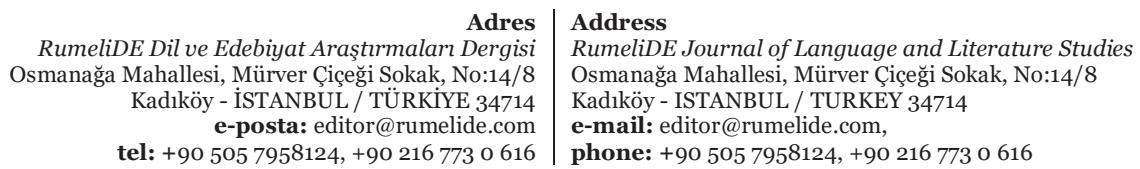


a) Yabancı dil Almanca öğretmen adaylarını öğretmenlik mesleğine yönelik tutumları ile meslek alan seçimine yönelik motivasyonları olumludur. b) Bu tutumları ile meslek alan seçimindeki motivasyonda cinsiyet faktörünün ve sınıf derecesinin anlamlı bir etkisi yoktur. c) Yabancı dil öğretmen adaylarının cinsiyete göre meslek alan tercihlerinde etkili içsel ve dışsal alan seçim sebeplerin etki düzeyinde kadın adayların erkek adaylara oranla içsel alan motivasyonları, erkek adayların ise dışsal meslek alan motivasyonları daha yüksektir. d) Adayların cinsiyete göre mesleği ve alanı seçmelerinde etkisini göstermiş olan içsel ve dışsal meslek seçim sebeplerin etki düzeyinde de kadın adayların erkek adaylara oranla içsel meslek motivasyonları, erkek adayların ise dışsal meslek motivasyonları daha yüksektir. e) Adaylarının seçtikleri mesleğe yönelik tutumlarıyla alan seçim motivasyonları arasındaki ilişki pozitif ve manidardır. f) Öğretmenlik mesleğine yönelik tutum, meslek alan seçim motivasyonu, içsel alan ve dışsal alan meslek motivasyonun manidar etkileyicisidir. Bu neticeler sonucunda, kadın öğretmen adaylarının dışsal alan ve meslek motivasyonlarını, erkek adayların ise içsel alan ve meslek motivasyonlarını arttırabilecek çalışmalar düzenlenebilir. Daha başarılı bir meslek yaşamı için öğretmen adaylarının mesleğe yönelik olumlu tutum sergilemeleri sağlanmalıdır. Ayrıca öğretmen adaylarına yüksek meslek alan seçim motivasyonu sağlamak amacıyla farklı etkinlikler düzenlenmeli ve mesleklerinin ne derece önemli olduğu ve insan hayatına getirileri konusunda öğretmen adaylarına seminerler düzenlenmelidir.

Yapılan bu çalışmanın bazı sınırlılıkları bulunmaktadır. Araştırma sadece Anadolu Üniversitesinin Yabancı Diller Eğitimi Bölümü Almanca Öğretmenliği Bölümü öğretmen adayları ile gerçekleştirilmiş ve Pandemi sebebi ile çalışmaya katılan örneklem grubuyla kısıtlı kalmıştır.

Yabancı dil Almanca alanında yapılmış olan bu araştırma Eğitim Fakültelerinin diğer alanlarında öğretmen adaylarıyla yapılan araştırma sonuçları ile karşılaştırılmıştır. Yapılmış olan bu çalışmada ulaşılan bulguların farklı üniversitelerin aynı alanda yapacakları araştırmalarla desteklenmesi büyük önem arz etmektedir.

\section{Kaynakça}

Acat, M.B.\& Demiral, S. (2002). Türkiye'de Yabancı Dil Öğreniminde Motivasyon Kaynakları ve Sorunları, Kuramdan Uygulamaya Eğitim Yönetimi, 8 (31) 312-329.

Acat, M. B. \& Yenilmez, K. (2004). Eğitim fakültesi öğrencilerinin öğretmenlik mesleğine ilişkin motivasyon düzeyleri. Kırgızistan-Türkiye: Manas Üniversitesi, Sosyal Bilimler Dergisi, 12, 125139.

Açışlı, S. \& Kolomuç, A. (2012). Sınıf öğretmeni adaylarının öğretmenlik mesleğine yönelik tutumlarının incelenmesi. Ĕ̆itim ve Öğretim Araştırmaları Dergisi, 1 (2), 266-271.

Aksoy, M.E. (2010). Öğretmen adaylarının öğretmenlik mesleğine ilişkin tutumları Gaziosmanpaşa Üniversitesi örneği. Mehmet Akif Ersoy Sosyal Bilimler Araştırmaları Dergisi, 2, 197-212.

Alyaz, Y. (2011). Alman Dili Ĕ̆itimi Anabilim Dalı Öğrencilerinin Dilsel Seviyeleri ve Almancaya İlişkin Tutumları". UÜ Eğitim Fakültesi Dergisi 24 (2): 503-525.

Atav, E. ve Altunoğlu, B. D. (2013). Meslek ve alan seçiminde motivasyon ölçeğinin Türkçe formunun geçerlik ve güvenirlik çalışması. Hacettepe Üniversitesi Ĕ̆itim Fakültesi Dergisi, 28(2), 58-70.

Atmaca, H. (2015). Yabancı Dil Öğretmen Adaylarının Öğretmenlik Mesleğine İlişkin Tutumlarının İncelenmesi. Uludağ Üniversitesi Eğitim Fakültesi Dergisi, 28 (Özel Sayı), 401-411.

Aydın, A. (2010). Eğitim psikolojisi. Ankara: Pegem A Yayıncılık.

Aydın, R. ve Sağlam, G. (2012). Öğretmen adaylarının öğretmenlik mesleğine yönelik tutumlarının belirlenmesi. Mehmet Akif Ersoy Üniversitesi örneği. Türk Eğitim Bilimleri Dergisi, 10/2, 257294.

\footnotetext{
Adres $\mid$ Address

RumeliDE Dil ve Edebiyat Araştırmaları Dergisi Rumelí E Dil ve Edebiyat Araştırmaları Dergisi
Osmanağa Mahallesi, Mürver Çiçeği Sokak, No:14/8 Kadıköy - İSTANBUL / TÜRKIYE 34714 e-posta: editor@rumelide.com

RumeliDE Journal of Language and Literature Studies

Osmanağa Mahallesi, Mürver Çiçeği Sokak, No:14/8

Kadıköy - ISTANBUL / TURKEY 34714

e-mail: editor@rumelide.com,

tel: +90 5057958124, +902167730616 phone: +90 5057958124, +90 2167730616
} 
810 / RumeliDE Journal of Language and Literature Studies 2022.26 (February)

The relationship between German pre-service teachers' attitudes towards teaching profession and their motivation on profession choice / Ş. Çelikkaya (pp. 795-813)

Bedel, E.F. (2008). Okulöncesi Öğretmen Adaylarının Öğretmenlik Mesleğine İlişkin Tutumları ve Bazı Kişilik Özellikleri Arasındaki İlişkiler. Eğitimde Kuram ve Uygulama, 4 (1), 31-48.

Bozdoğan A. E., Aydın D. ve Yıldırım, K. (2007). Ö $\breve{g r e t m e n ~ a d a y l a r ı n ı n ~ o ̈ g ̆ r e t m e n l i k ~ m e s l e g ̆ i n e ~ i l i s ̧ k i n ~}$ tutumları. Ahi Evran Üniversitesi Kırşehir Eğitim Fakültesi Dergisi, 8/2, 83-97.

Bulut, D., (2011). Müzik Öğretmeni Adaylarının Öğretmenlik Mesleğine Yönelik Tutumları, Gazi Üniversitesi Gazi Eğitim Fakültesi Dergisi, Cilt:31, Sayı:3, 651-674.

Chen, A. (2001). A theoretical conceptualization for motivation research in physical education: An integrated perspective. Quest, 2, 35-58.

Çağlar, Ç. (2013). Eğitim fakültesi öğrencilerinin öğrenme ortamına ilişkin adalet algıları ile öğretmenlik mesleğine yönelik tutumları arasındaki ilişki. Elektronik Sosyal Bilimler Dergisi, 12(46), 50-69.

Çeliköz, N. ve Çetin, F. (2004). Anadolu Öğretmen Lisesi Öğrencilerinin Öğretmenlik Mesleğine Yönelik Tutumlarını Etkileyen Etmenler. Milli Ĕ̆itim Dergisi, 162, 160-167.

Çetinkaya, Z. (2009). Türkçe öğretmen adaylarının öğretmenlik mesleğine ilişkin tutumlarının belirlenmesi. İlköğretim Online, 8/2, 298- 305 .

Çiçek-Sağlam, A. (2008). Müzik öğretmenliği bölümü öğrencilerinin öğretmenlik mesleğine yönelik tutumları. Yüzüncü Yıl Üniversitesi Eğitim Fakültesi Dergisi, 5 (1), 59-69.

Dann, H. D., \& Lechner, T. (2001). Berufswahlmotive Nürnberger Lehramtsstudierender.Mitteilungen der Erziehungswissenschaftlichen Fakultät. Universität Erlangen-Nürnberg, 1-3.

Dellal, N. A-Günak, D.B. (2009). “Çanakkale Onsekiz Mart Üniversitesi’nde İkinci Yabancı Dil Olarak Almanca Öğrenen Öğrencilerin Öğrenme Motivasyonları”. Dil Dergisi (143): 20-41.

Demircioğlu, E. ve Özdemir, M. (2014). Fen ve edebiyat fakültesi öğrencilerinin öğretmenlik mesleğine yönelik tutumlarının çeşitli değişkenlere göre incelenmesi. Mersin Üniversitesi Eğitim Fakültesi Dergisi, 10/3, 110-122.

Demirel, Ö. (1999) Planlamadan Değerlendirmeye Öğretme Sanatı. Ankara: Pegem Akademi.

Demirel, Ö. (2003). Eğitim sözlüğü. Ankara: Pegem A Yayıncılık.

Demirtaş, H., Cömert, M. \& Özer, N. (2011). Öğretmen adaylarının özyeterlik inançları ve öğretmenlik mesleğine ilişkin tutumları. Ĕ̆itim ve Bilim, 36(159), 96-111.

Dereli, E., Acat M. B. (2010).“Okul Öncesi Eğitim Öğretmenliği Bölümü Öğrencilerinin Motivasyon Kaynakları ve Sorunları”. Selçuk Üniversitesi Sosyal Bilimler Enstitüsü Dergisi. 24; 173-187.

Edelmann, Walter (2003). "Intrinsische und extrinsische Motivation”. Grundschule (4): 30-32.

Ercan, L. (2000). Motivasyon (Güdülenme). Leyla Küçükahmet (Ed.). Sınıf yönetiminde yeni yaklaşımlar (107-122). Ankara: Nobel.

Erden, M. (1998). Öğretmenlik Mesleğine Giriş. İstanbul: Alkım Yayınları.

Eren, E. (2012). Örgütsel davranış ve yönetim psikolojisi. (13.Baskı). İstanbul: Beta Basım YayımDağıtım.

Gardner, R.C. \& Lambert, W.E. (1972). Attitudes and motivation in second language learning. Rowley, MA: Newbury House.

Gençay, Ö. A. \& Gençay, S. (2007). Beden eğitimi ve spor yüksekokulu öğrencilerinin öğretmenlik mesleğine ilişkin motivasyon düzeylerinin bazı değiş̧kenler açısından incelenmesi. Selçuk Üniversitesi Sosyal Bilimler Enstitüsü Dergisi, 17, 241-255.

Güdek, B., (2007). Müzik Öğretmenliği Bilim Dalı, Eğitim Fakültesi Müzik Eğitimi Anabilim Dalı 1. ve 4. Sinıf, Öğrencilerinin Müzik Öğretmenliği Mesleğine Yönelik Tutumlarının Öğrenciye Ait Farklı Değişkenler Açısından İncelenmesi, Yayınlanmamış Doktora Tezi, Gazi Üniversitesi, Eğitim Bilimleri Enstitüsü, Ankara.

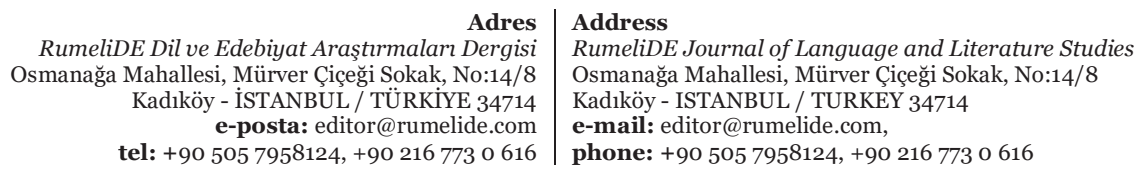


RumeliDE Dil ve Edebiyat Araştırmaları Dergisi 2022.26 (Şubat)/ 811

Almanca öğretmen adaylarını öğretmenlik mesleğine yönelik tutumları ile meslek alan seçimindeki motivasyonları arasındaki ilişki / Ș. Çelikkaya (795-813. s.)

Işık, S. Yaman, M. Soran, H. (2005). Biyoloji ve Biyoloji öğretmenliğine Karşı Tutumlarına Göre Biyoloji Öğretmen Adaylarının Tiplerinin Belirlenmesi. Hacettepe Üniversitesi Eğitim Fakültesi Dergisi, 29 (29), 110-116.

İlter, İ. ve Köksalan, B. (2011). Sınıf öğretmeni adaylarının öğretmenlik mesleğine olan tutumları. Fırat Üniversitesi Sosyal Bilimler Dergisi, 21/1, 113-128.

İnceoğlu, M. (2004). Tutum, algı, iletişim. Ankara: Kesit Tanıtım Ltd. Şti.

İşigüzel, B. (2012). "Motivasyon: Yabancı Dil Dersinin Hormonu”. Mersin Üniversitesi Eğitim Fakültesi Dergisi, 7 (1): 29-41.

Karasar, N. (2008). Bilimsel araştırma yöntemleri. Ankara: Nobel Yayın-Dağıtım.

Kaya, Z. (2001). Bir Meslek Olarak Öğretmenlik ve Öğretmenlik Mesleğine Giriş. Ankara: Pegem Yayınlarl.

Kaya, A., Büyükkasap, E. (2005). Fizik Öğretmenliği Programı Öğrencilerinin Profilleri, Öğretmenlik Mesleğine Yönelik Tutum ve Endişeleri: Erzurum Örneği. Kastamonu Eğitim Dergisi, 13(2), 367380 .

Kayhan, A. Baysan, O. Alcı. B. (2018). Öğretmen Adaylarının Öğretmenlik Mesleğine Yönelik Tutumlarının Farklı Değişkenler Açısından İncelenmesi. Akademik Sosyal Araştırmalar Dergisi, Yıl: 6, Sayı: 72, Haziran, s. 545-559.

Kızıltepe, Z. (1999). Türk öğrencilerin yabancı dil öğrenimine olan tutumları ve güdüleri. Dil Dergisi, 81, 5-19.

Köydemir F. (2004). "Dokuz Eylül Üniversitesi Alman Dili Eğitimi Anabilim Dalı ile Ege Üniversitesi Alman Dili ve Edebiyatı Anabilim Dalı Öğrencilerinin Kendi Anabilim Dallarına ve Almancaya Yönelik Tutumları Konusunda Karşılaştırmalı Bir Araştırma.” Yayımlanmamış yüksek lisans tezi, Sosyal Bilimler Enstitüsü: İzmir.

Küçük, O. (2007). Almanca Eğitimi Alan Öğrencilerinin Almanca Dersine Yönelik Tutumlarının Çeşitli Değişkenlere Göre İncelenmesi. (Yayımlanmamış Yüksek Lisans Tezi). Selçuk Üniversitesi, Konya.

Küçükosmanoğlu, H. O. (2015). Müzik öğretmeni adaylarının akademik motivasyon düzeylerinin belirlenmesi üzerine bir çalışma (Konya ili örneği). Sanat Ĕ̆itimi Dergisi. 3(1), 1-21.

List, G. (2002). “Motivation im Sprachunterricht”. Fremdsprache Deutsch, Heft 26/2002, 6-10.

Martin, R. \& Steffgen, G. (2002). Zum Einfluss der Berufswahlmotive auf die Berufszufriedenheit von Grundschullehrern. Psychologie in Erziehung und Unterricht, 49(4), 241-249.

Mayr, J. (1998). Motive für die studien- und berufswahl. fragebögen zur erkundung des lehrens und lernens an der pädagogischen akademie. Eine Materialsammlung. Pädagogische Akademie der Diözese Linz.

MEB. (2017). Ulusal Öğretmen Strateji Belgesi 2017-2023. Ankara. Öğretmen Yetiştirme ve Geliştirme Genel Müdürlüğü.

MEB. (2017). Öğretmenlik mesleği genel yeterlikleri. Öğretmen Yetiştirme ve Geliştirme Genel Müdürlüğü, Ankara. meb.gov.tr/www/ogretmenlik-meslegi-genel-yeterlikleri/icerik/39. Erişim tarihi.15.07.2020.

Özbek, R., Kahyaoğlu, M. \& Özgen, N. (2007). Öğretmen adaylarının öğretmenlik mesleğine yönelik görüşlerinin değerlendirilmesi. Afyon Kocatepe Üniversitesi Sosyal Bilimler Dergisi, 9 (2), 221232.

Özdemir, S. ve Yalın H. İ. (2000). “Öğretmenlik mesleğine giriş” (3. Basım). Nobel yayın dağıtım, Ankara.

Özgüngör, S., \& Kapıkıran, Ş. (2008). Güzel sanatlar eğitimi öğrencilerinin öğretmenlik meslek bilgisi derslerine ilişkin motivasyon ve başarı düzeyleri. Pamukkale Üniversitesi Eğitim Fakültesi Dergisi, (1)23, 47-60.

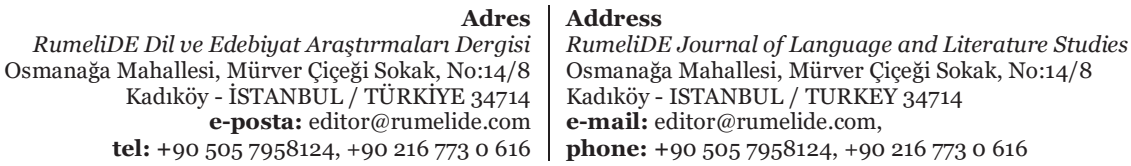


812 / RumeliDE Journal of Language and Literature Studies 2022.26 (February)

The relationship between German pre-service teachers' attitudes towards teaching profession and their motivation on profession choice / Ş. Çelikkaya (pp. 795-813)

Özkan, H. H. (2012). Öğretmenlik formasyon programındaki öğretmen adaylarının öğretmenlik mesleğine ilişkin tutumlarının incelenmesi (SDÜ örneği). Ahi Evran Üniversitesi Kırşehir Eğitim Fakültesi Dergisi (KEFAD), 12(2), 29-48.

Özkubat, S. \& Demiriz, S. (2013). Çevreye karşı motivasyon ölçeğinin okul öncesi öğretmen adayları üzerinde geçerlik güvenirlik çalışması. Amasya Üniversitesi Eğitim Fakültesi Dergisi, 2 (1), 87114 .

Özsoy, G., Özsoy, S., Özkara, Y. ve Memiş, A. D. (2010). Factors affecting pre-service teachers' choice of teaching as a profession. Elementary Education Online, 9(3), 910-921.

Öztürk Akar, E. (2012). Motivations of turkish pre-service teachers to choose teaching as a career. Australian Journal of Teacher Education, 37(10).

Pehlivan, K. (2008). Sınıf öğretmeni adaylarının sosyo-kültürel özellikleri ve öğretmenlik mesleğine yönelik tutumları üzerine bir çalışma. Mersin Üniversitesi Eğitim Fakültesi Dergisi, 4 (2), 151168.

Ryan, R.M ve Deci, EL (2000) "İçsel ve dış Motivasyonları: Klasik Tanımlar ve Yeni Talimatlar", Çağdaş Eğitim Psikolojisi , No.25: 54-67.

Sağlam, A. Ç. (2007). Eğitim örgütlerinde kuramdan uygulamaya güdüleme. Ankara: Nobel.

Saracaloğlu, A. S. \& Dinçer, I. B. (2009). A study on correlation between self-efficacy and academic motivation of prospective teachers. Procedia - Social and Behavioral Sciences, 1(1), 320-325.

Sarıer, Y. (2016). “Türkiye’de Öğrencilerin Akademik Başarısını Etkileyen Faktörler: Bir Meta-Analiz Çalışması”. Hacettepe Üniversitesi Eğitim Fakültesi Dergisi (H. U. Journal of Education) 31 (3): 609-627.

Şahin, H \& Çakar, E. (2011). Ĕ̆itim fakültesi öğrencilerinin öğrenme stratejileri ve akademik güdülenme düzeylerinin akademik başarılarına etkisi. Türk Eğitim Bilimleri Dergisi, 9(3), 519-540.

Şimşek, H. (2005). Ortaöğretim alan öğretmenliği tezsiz yüksek lisans programına devam eden öğrencilerin öğretmenlik mesleğine yönelik tutumları. Yüzüncü Yıl Üniversitesi Elektronik Eğitim Fakültesi Dergisi, 2(1).

Şişman, M. (2000). Öğretmenliğe giriş (2.baskı). Pegem yayıncılık, Ankara.

Terzi, A. R. ve Tezci, E. (2007). "Necati Bey Eğitim Fakültesi Öğrencilerinin Öğretmenlik Mesleğine İlişkin Tutumları”, Kuram ve Uygulamada Eğitim Yönetimi. S.13(52), ss.593-614.

Tezbaşaran, A. (1997). Likert tipi ölçek geliştirme kılavuzu. Ankara: Türk Psikologlar Derneği Yayınları.

Ulich, K. (2004). Ich will Lehrer/in werden. Eine Untersuchung $\mathrm{zu}$ den Berufsmotiven von Studierenden. Weinheim: Beltz.

Ulutaş, B. (2016). Özdüzenlemeli öğrenme ortamında kimya öğretmen adaylarının motivasyonlarının değişiminin incelenmesi. Yayımlanmamış Doktora Tezi. Ankara: Gazi Üniversitesi Eğitim Bilimleri Enstitüsü.

Urhahne, D. (2006). Ich will Biologielehrer werden!, Zeitschrift für Didaktik der Naturwissenschaften; Jg. 12, 111125 .

Uslu, Z.; Özek, Y. (2004). "Yabancı Dil Öğretmeni Adaylarının İkinci Yabancı Dili Öğrenmeye İlişkin Tutum ve Görüşleri”. İÜ Hasan Ali Yücel Eğitim Fakültesi Dergisi (2): 129-140.

Uyanık, G. (2017). Sınıf Öğretmeni Adaylarının Öğretmenlik Mesleğine Yönelik Tutumlarının Çeşitli Değişkenlere Göre İncelenmesi: Boylamsal Bir Araştırma. Türk Eğitim Bilimleri Dergisi. 10(2): 185-195.

Uyulgan, M. A., Akkuzu, N. (2014). Öğretmen Adaylarının Akademik İçsel Motivasyonlarına Bir Bakış. Dokuz Eylül Üniversitesi. Kuram ve Uygulamada Ĕ̆itim Bilimleri. 14(1), 7-32.

Ünal, F., Bursalı, H. (2013). Türkçe Öğretmenlerinin Motivasyon Faktörlerine İlişkin Görüşleri. Middle Eastern \& African Journal of Educational Research, Issue 5, 7-16.

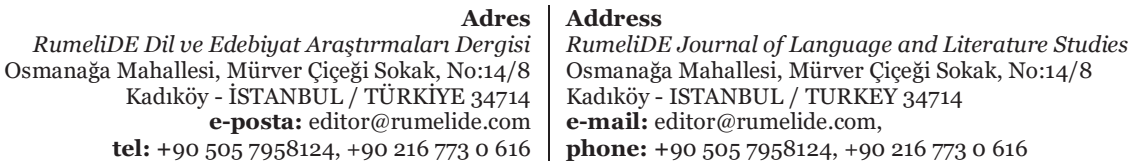


Üstün, E., Erkan, S. ve Akman, B. (2004). Türkiye'de Okulöncesi Öğretmenliği Öğrencilerinin Öğretmenlik Mesleğine Yönelik Tutumlarının İncelenmesi. Kırgızistan-Türkiye Manas Üniversitesi Bilimler Dergisi, 10, 129-136.

Üstüner, M. (2006). Öğretmenlik mesleğine yönelik tutum ölçeğinin geçerlik ve güvenirlik çalışması. Kuram ve Uygulamada Eğitim Yönetimi, 45, 109-127.

Wicke R. (2004). Aktiv und Kreativ Lernen. Projektorientierte Spracharbeit im Unterricht Deutsch als Fremdsprache. Hueber.

Woolfolk, A.E.(1999). Educational Pyschology. Seventh Edition. Allyn and Bacon Publishing.

Yeşil, R. ve Çalışkan, N. (2006). Okul Deneyimi I Dersinden Öğrencilerin Beklentileri ve Bu Beklentilerin Karşlanma Düzeyi, Türk Eğitim Bilimleri Dergisi,4(1), 55-72.

Young, B.J. (1995). Career plans and work perception of pre-service teachers. Teaching and Teacher Education, 11, 281-292.

RumeliDE Dil ve Edebiyat Araştırmaları Dergis Osmanağa Mahallesi, Mürver Çiçeği Sokak, No:14/8 Kadıköy - İSTANBUL / TÜRKIYE 34714 tel: $+905057958124,+902167730616$
RumeliDE Journal of Language and Literature Studies Osmanağa Mahallesi, Mürver Çiçeği Sokak, No:14/8 Kadıköy - ISTANBUL / TURKEY 34714 e-mail: editor@rumelide.com

phone: +90 $5057958124,+902167730616$ 